\title{
Male dominance linked to size and age, but not to 'good genes' in brown trout (Salmo trutta)
}

\author{
Alain Jacob*1,2, Sébastien Nusslé1, Adrian Britschgi ${ }^{2}$, Guillaume Evanno ${ }^{1}$, \\ Rudolf Müller ${ }^{3}$ and Claus Wedekind ${ }^{1,2,3}$
}

Address: ${ }^{1}$ Department of Ecology and Evolution, University of Lausanne, Biophore, 1015 Lausanne, Switzerland, ${ }^{2}$ Division of Conservation Biology, University of Bern, Erlachstrasse 9a, 3012 Bern, Switzerland and ${ }^{3}$ Eawag: Swiss Federal Institute of Aquatic Science and Technology, Seestrasse 79, 6047 Kastanienbaum, Switzerland

Email: Alain Jacob* - alain.jacob@unil.ch; Sébastien Nusslé - sebastien.nussle@unil.ch; Adrian Britschgi - adrian.britschgi@dkf.unibe.ch; Guillaume Evanno - guillaume.evanno@unil.ch; Rudolf Müller - rudolf.mueller@eawag.ch; Claus Wedekind - claus.wedekind@unil.ch

* Corresponding author

Published: I November 2007

BMC Evolutionary Biology 2007, 7:207 doi: I0.1 I86/147/-2/48-7-207
Received: 19 July 2007

Accepted: I November 2007

This article is available from: http://www.biomedcentral.com//47I-2/48/7/207

(c) 2007 Jacob et al; licensee BioMed Central Ltd.

This is an Open Access article distributed under the terms of the Creative Commons Attribution License (http://creativecommons.org/licenses/by/2.0), which permits unrestricted use, distribution, and reproduction in any medium, provided the original work is properly cited.

\begin{abstract}
Background: Males that are successful in intra-sexual competition are often assumed to be of superior quality. In the mating system of most salmonid species, intensive dominance fights are common and the winners monopolise most mates and sire most offspring. We drew a random sample of mature male brown trout (Salmo trutta) from two wild populations and determined their dominance hierarchy or traits linked to dominance. The fish were then stripped and their sperm was used for in vitro fertilisations in two full-factorial breeding designs. We recorded embryo viability until hatching in both experiments, and juvenile survival during 20 months after release into a natural streamlet in the second experiment. Since offspring of brown trout get only genes from their fathers, we used offspring survival as a quality measure to test (i) whether males differ in their genetic quality, and if so, (ii) whether dominance or traits linked to dominance reveal 'good genes'.

Results: We found significant additive genetic variance on embryo survival, i.e. males differed in their genetic quality. Older, heavier and larger males were more successful in intra-sexual selection. However, neither dominance nor dominance indicators like body length, weight or age were significantly linked to genetic quality measured as embryo or juvenile survival.

Conclusion: We found no evidence that females can improve their offspring's genetic viability by mating with large and dominant males. If there still were advantages of mating with dominant males, they may be linked to non-genetic benefits or to genetic advantages that are context dependent and therefore possibly not revealed under our experimental conditions - even if we found significant additive genetic variation for embryo viability under such conditions.
\end{abstract}

\section{Background}

In mating systems with elaborate male-male competition, the winners usually get most mates and sire most of the offspring [1-10]. Such a skewed male mating success may either be explained by physically limited access of subdominant males to females and/or by female preference for dominant males [11-13]. Females may prefer more dominant and more attractive males because they provide more resources, better parental care $[14,15]$ or better genes for the common offspring [2,16-18]. The 
latter hypothesis corresponds to the so-called 'good-genes' hypotheses of sexual selection, i.e. variation in genetic quality is then predicted to be linked to male characteristics that influence female mate choice. The problem of how such genetic variation can be maintained under sexual selection is known as the "lek paradox" [19], and a number of possible solutions for this paradox have been offered (reviewed in $[20,21]$ ). Although it is still not fully clear how the genetic variation is maintained, there is much evidence in various species that females can gain genetic advantages by preferring males with well-developed attractiveness traits [22]. Whether females gain genetic benefits by mating with dominant males is less clear.

Experimental tests of the 'good-genes' hypotheses of sexual selection usually suffer from at least one of two problems: First, the predicted genetic effects could be confounded with non-genetic effects. This is especially so in species with some form of parental care. Males with more elaborate secondary sexual characters could, for example provide good genes and much paternal care $[23,24]$. Second, females sometimes adjust their investment in the offspring (e.g. yolk quality in egg) according to their perception of male attractiveness $[25,26]$. As a consequence of such differential allocation, 'good genes' effects can be confounded with maternal effects. However, some recent in vitro fertilization experiments could control for these potential confounding factors. They demonstrate that offspring viability can indeed have a genetic basis that is revealed by potential attractiveness traits $[27,28]$. In salmonids, not much is known about female preference for attractiveness traits, but males usually fight intensely for access to spawning territories or to females, i.e. intra-sexual selection is often very important $[1,8,29$ 34]. Females seem to generally prefer spawning with dominant males $[8,35,36]$. Here we test whether male characteristics that are important in intra-sexual selection are also linked to genetic quality.

'Genetic quality' is, in the context of sexual selection, an umbrella term that includes additive ('good genes') and non-additive genetic effects ('compatible genes') on offspring survival [16]. If male dominance is linked to genetic quality and also positively to breeding success, we predict dominance to be linked to the additive genetic variance in fitness, i.e. to variation in 'good genes', since only additive genetic effects can lead to an universally valid order of mate quality while with non-additive genetic effects the order of mate quality would differ for different females [18]. Because embryogenesis is a crucial life-history stage with usually high mortalities $[37,38]$, and male brown trout provide only genes to their offspring, we used embryo survival as a measure of genetic quality, and we used full-factorial breeding designs to separate and compare additive and non-additive genetic effects on embryo survival.

In a first experiment we caught brown trouts (Salmo trutta forma fario, Salmonidae), shortly before spawning season and released them into an artificial channel to study intrasexual selection. We used the outcomes of all male fights to construct a dominance hierarchy and to test whether there are male characteristics that are linked to dominance. We stripped the fish and used their gametes in a 10 males $\times 8$ females full-factorial breeding design (North Carolina II design [39]). The embryos of the resulting 80 families were raised individually under controlled conditions. We then tested whether males differed in their genetic quality, and if so, whether dominance indicators are linked to superior genetic quality. The last two questions were tested again in a second experiment where we determined and analysed embryo and juvenile survival of additional 13 brown trout males from another river. In the first experiment we found that older, heavier and larger males are more dominant in male-male interactions. In both experiments males differ in their genetic quality, but dominant males do not seem to be of superior genetic quality.

\section{Results \\ First experiment}

Two males were 2 years old, 5 males were 3 years old and 3 males were 4 years old (their body lengths are plotted in Figure 1). Male age, body weight, and body length were all strongly correlated to each other ( $r$ always $\geq 0.93, n=10$, $\mathrm{p}$ always $<0.0001)$. Larger males were on average more dominant (Figure 1; with David's score (DS): Spearman's rank order correlation coefficient $\mathrm{r}_{\mathrm{s}}=0.75, \mathrm{p}=0.015$; and with Clutton-Brock et al.'s index (CBI): $\mathrm{r}_{\mathrm{s}}=0.68, \mathrm{p}=$ 0.035). We found analogous positive relationship between dominance and male age (DS: $r_{s}=0.82, p=$ 0.006; CBI: $r_{s}=0.72, p=0.02$ ) or male weight (DS: $r_{s}=$ 0.73, $\mathrm{p}=0.02$; CBI: $\mathrm{r}_{\mathrm{s}}=0.64, \mathrm{p}=0.05, \mathrm{n}$ always $=10$ ).

Average embryo survival was $77.9 \%$ ( \pm 11.3 s.d.). Offspring of different females differed in their survival as the female effect explained a significant part of the variance in offspring mortality (the model without female effect (male model) differed significantly in its goodness of fit from the reference model; Table 1). Males also differed significantly in their offspring survival (i.e. the model without the male effect (female model) explains significantly less variance in offspring mortality than the reference model; Table 1). We found no significant male $\times$ female interaction effect on embryo survival (Table 1). The AICs of the different models and the differences between the AICs also indicate that the reference model is the most parsimonious one that fits our data best (see Table 1 for details). The fixed temperature effect in the reference model 


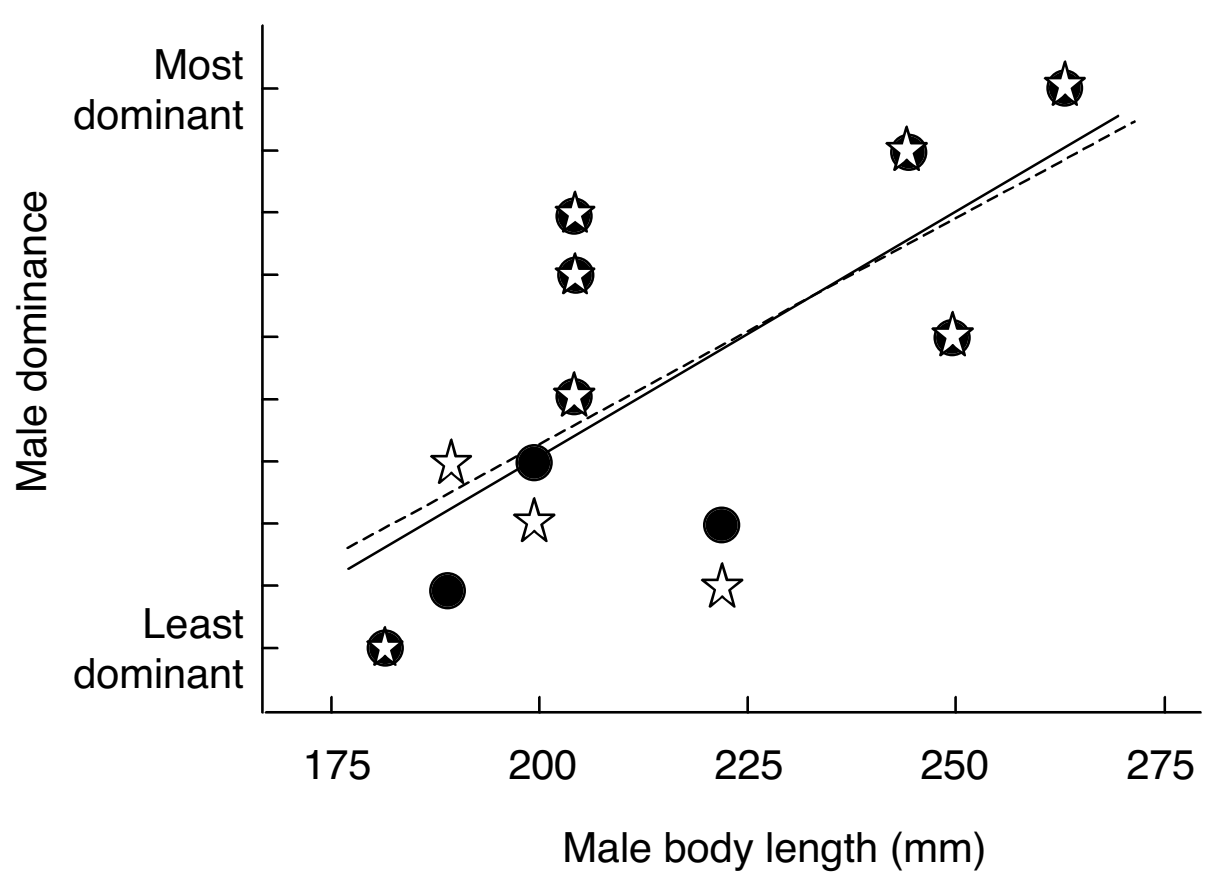

\section{Figure I}

The effect of male body length on dominance in male-male interactions. Dominance is given as David's score (circles and non-dashed regression line) and as Clutton-Brock et al.'s index (stars and dashed line). Both scores are based on 198 antagonistic encounters.

was not found to have a significant influence on embryo mortality $(\mathrm{Z}=-1.718, \mathrm{p}=0.086)$.

Embryo survival was not positively linked to male dominance (DS: $\mathrm{r}_{\mathrm{s}}=-0.47, \mathrm{p}=0.18 ; \mathrm{CBI}: \mathrm{r}_{\mathrm{s}}=-0.48, \mathrm{p}=0.17 ; \mathrm{n}$ always $=10$ ) and male body length (Figure 2 ). The 95\% confidence interval for the latter correlation is $-0.827<\mathrm{r}<$ 0.295 . A power analysis revealed that if the correlation between male length and offspring viability were at the upper limit of our calculated confidence interval, a minimal sample size of 88 males and more than 21,300 experimentally fertilized eggs would be necessary to demonstrate the effect at alpha $\leq 0.05$ with our experimental methods and with a statistical power of at least $80 \%$. Since this power analysis is for a possible correlation at the upper extreme of our observed confidence interval, we conclude that there is no or only a very weak positive correlation between male length and offspring survival. There was also no positive link between embryo survival and male age $(\mathrm{r}=-0.50, \mathrm{n}=10, \mathrm{p}=0.14)$ or weight $(\mathrm{r}=$ $0.40, \mathrm{n}=10, \mathrm{p}=0.25)$.

\section{Second experiment}

Male age ranged from 3 to 7 years (mean $=4.9 \pm 1.2$ (s.d.)). Average embryo survival was $42.1 \%$ ( \pm 10.0 s.d.). We found again significant sire effects on embryo survival (Table 2), i.e. the males differed in genetic quality. We also found maternal effects on embryo survival, but no significant sire $\times$ dam interaction (Table 2). Embryo survival was again not significantly linked to male age $(\mathrm{r}=$ $0.19, \mathrm{n}=13, \mathrm{p}=0.54)$, body weight $(\mathrm{r}=-0.22, \mathrm{n}=13, \mathrm{p}=$ 0.69 ), or body length (Figure 2 ). The correlation coefficient that describes the link between male body length and offspring viability in the second experiment (Figure 2) lies within the $95 \%$ confidence interval that we had obtained from the first experiment.

The statistical model in Table 2 explains a significant fraction of the total variance in embryo mortality. Dam effects include direct genetic effects, as well as maternal genetic and maternal environmental effects. Significant sire effects directly reveal variation in genetic quality. Assuming that epistatic genetic variance is of negligible 
Table I: The Influence of paternal, maternal and paternal $\times$ maternal interaction effects on embryo mortality in the $\mid$ st experiment.

\begin{tabular}{|c|c|c|c|c|c|c|c|c|c|c|}
\hline \multirow[b]{2}{*}{ Model } & \multirow[b]{2}{*}{$\begin{array}{l}\text { Effect } \\
\text { tested }\end{array}$} & \multicolumn{3}{|c|}{ Model parameters } & \multirow[b]{2}{*}{$\ln L$} & \multirow[b]{2}{*}{$A I C$} & \multirow[b]{2}{*}{$\triangle A I C$} & \multicolumn{3}{|c|}{$\begin{array}{l}\text { Likelihood ratio tests (LRT) with } \\
\text { reference model }\end{array}$} \\
\hline & & Random & Fixed & $\begin{array}{l}\text { Number } \\
(\mathrm{k})\end{array}$ & & & & $\chi^{2}$ & d.f. & $P$ \\
\hline $\begin{array}{l}\text { reference } \\
\text { model }\end{array}$ & & $F, M$ & $\mathrm{~T}$ & 3 & -280.19 & 568.38 & & & & \\
\hline full model & $\begin{array}{l}\text { Male } \times \\
\text { Female }\end{array}$ & $F, M, F \times M$ & $\mathrm{~T}$ & 4 & -280.19 & 570.38 & 2.00 & 0.00 & 1 & I \\
\hline $\begin{array}{l}\text { female } \\
\text { model }\end{array}$ & Male & $\mathrm{F}$ & $\mathrm{T}$ & 2 & -283.04 & 572.07 & 3.69 & 5.69 & 1 & 0.017 \\
\hline male model & Female & $M$ & $\mathrm{~T}$ & 2 & -403.65 & 813.30 & 244.92 & 246.92 & I & $<0.0001$ \\
\hline
\end{tabular}

Four logistic mixed effect models are compared to test if male $(M)$, female $(F)$, and male $\times$ female interaction $(M \times F)$ effects explain a significant part of the variance in embryo mortality (a binary response variable; egg number $n=2028$ ). The random, fixed, and total number $(k)$ of parameters are given for every model. The goodness of fit is given by the logarithm of the approximated likelihood $(\ln L)$ and the Akaikes information criterion (AIC). A measure to compare the quality of fit between two models is the difference of AICs ( $\triangle A I C)$ between two models. The reference model explains our data best as the more complex full model does not significantly improve the qualtiy of fit (see $\triangle A I C ;$ LRT), i.e. the male $\times$ female interaction effect did not explain a significant part of the variance in embryo mortality. The table therefore gives the differences in AICs between the reference model and the other models. Furthermore, likelihood ratio tests (LRT) between the reference model and the other models are given to test which parameter significantly improves the goodness of fit.

Table 2: Variance component analyses on embryo mortality in the $2^{\text {nd }}$ experiment.

\begin{tabular}{llllll}
\hline & SS & d.f. & $F$ & $P$ & $\sigma^{2}(\%$ of total) \\
\hline Sire & 1.80 & 12 & 2.5 & 0.01 & $0.005023(7.3 \%)$ \\
Dam & 0.85 & 5 & 2.8 & 0.02 & $0.002818(4.1 \%)$ \\
Sire $\times$ dam & 3.58 & 60 & 1.0 & 0.53 & $0(0 \%)$ \\
Total & & & & $0.068507(100 \%)$ \\
\hline
\end{tabular}

Two-way ANOVA on embryo mortalities observed in the second breeding experiment when 13 males are crossed with 6 females in a full-factorial design and the embryos raised in 3 Petri dishes per sibship. Because the experimental set-up is fully balanced, results are based on EMS (Expected Mean Square). Sire, dam, and sire $\times$ dam interaction were random effects in the model. The negative estimate for the variance component of the interaction term is put to zero.

importance, the additive genetic variance can be calculated as four times the sire component of variance $[16,39]$ and explains, in our second experiment, about 29.3\% (4 $\times 0.005023 / 0.0 .068507$, see Table 2 ) of the total phenotypic variance in embryo mortality. The dam $\times$ sire effect can be used to estimate the non-additive genetic variance which here represents $0 \%$ of the total phenotypic variance in embryo mortality. The difference between the dam and sire component of variance is negative, i.e. the total maternal effect variance seems to be very low in the six females we used here.

We released 2443 hatchlings from this $2^{\text {nd }}$ experiment into the streamlet. Nineteen juveniles could be caught back 20 months later (overall juvenile survival $=0.8 \%$ ). Juvenile survival was not significantly linked to embryo survival (Figure 3a), and there was no significant positive relationship between juvenile survival and sire body length (Figure $3 \mathrm{~b})$, body weight $\left(-\mathrm{r}_{\mathrm{s}}=0.14, \mathrm{n}=13, \mathrm{p}=\right.$ $0.65)$, or age $\left(-r_{s}=0.42, n=13, p=0.16\right)$.

\section{Discussion}

Our first experiment shows that larger, heavier and older males were more dominant in male-male interactions than smaller, lighter and younger ones. This supports findings on other salmonid species where size was a good indicator for dominance status $[9,29,40-43]$. We have to leave it open whether body length, weight, or age is the better predictor for dominance rank as they were, as expected [44], highly correlated to each other. We used embryo survival until hatching as a main measure of sire 'good genes' because embryogenesis is a critical stage in offspring development (> 50\% of offspring mortality normally happens at this stage under natural conditions $[37,38])$.

We found in both experiments that males differ in their offspring survival. We also tested for female effects on offspring survival. Such latter effects could be explained by differences in genetic quality among the females and/or by differences in egg quality. Variation in egg quality 


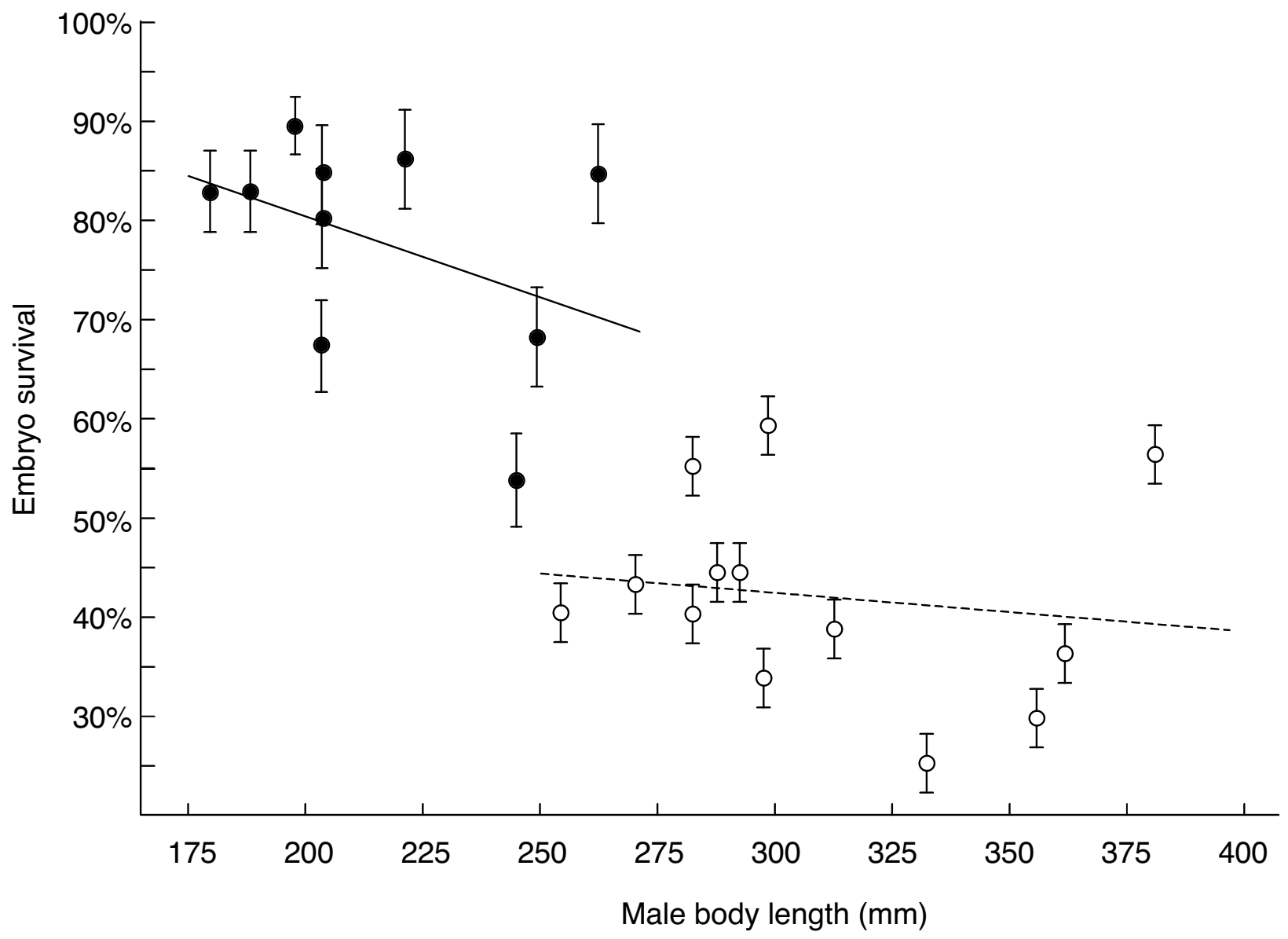

Figure 2

Embryo survival until hatching (means \pm SE) versus male body length. The survival of visible embryos until hatching, i.e. excluding apparently non-fertilized eggs, for the first experiment (river "Müsche"; filled symbols and non-dashed regression line; Pearson's $r=-0.41, n=10, p=0.24$ ), and total embryo survival for the second experiment (river "Enziwigger", open symbols and dashed regression line; $r=-0.15, n=13, p=0.63$ ).

could be linked to female age, condition, and/or life history. Such differences in female investment are expected to be a crucial factor for egg survival in this development stage [45-47]. Accordingly, we found evidence for significant maternal effects on embryo survival in both experiments. Our experimental setup allowed us to control for these female effects. Analogously, males may differ in their sperm quality (e.g. sperm velocity, sperm longevity and spermatocrit), which could influence their fertilisation success $[48,49]$. We controlled for these potential differences by including only fertilised eggs in our measure of embryo survival in the first experiment. The second experiment was done with males that did not differ significantly in their fertilization ability (Wedekind, unpublished data). Therefore the sire effect that we found is directly linked to differences in male genetic quality and reveals additive genetic variation in embryo viability.
Although males differed in the viability of their embryos and hence in their genetic quality, male dominance or dominance-related characteristics were no indicators of 'good genes'. A power analysis shows that the chance of missing an existing correlation (type II error) is very low. In a second experiment, offspring viability was determined at two stages, as embryo survival in the laboratory and as juvenile survival in the field. In this second experiment we found again differences in male genetic quality but no significant connection between dominance traits and 'good genes'. Hence, we found no support for the hypothesis that dominant males are genetically superior. This seems to be in agreement with previous studies on species with parental care where no link between fathers' dominance and offspring viability was found $[50,51]$, but the relative importance of variation in genetic quality and in parental care remains unclear in these studies. 


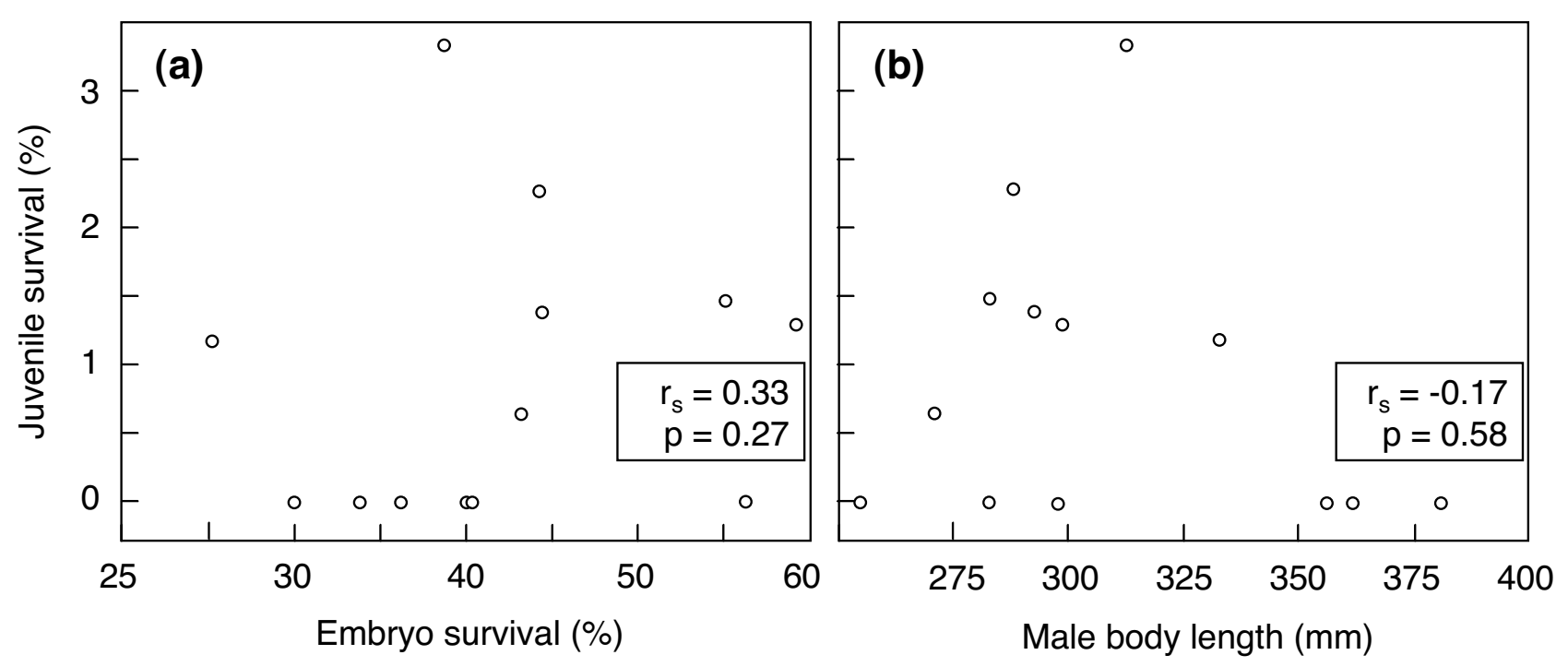

Figure 3

Juvenile survival in the field (means \pm SE) versus embryo survival and male body length. Juvenile survival during 20 months as determined in the second experiment (total number of juveniles/total number of released hatchlings). The inserts give the Spearman rank order coefficients $r_{s}$ and the two-tailed $p$-values.

Because male age, body length, body weight, and dominance are all strongly correlated in brown trout, we expect that older males will have a comparatively high reproductive success simply because they tend to be more dominant. However, according to our results females may not receive genetic benefits from mating with older males, contrary to some predictions from the literature [52-54]. It remains to be tested whether, for males that grow old, an original higher genetic quality is later in life reduced by an accumulation of germ-line mutations [52,55-57]. If so, larger and dominant males may still provide 'good genes' that may, however, only be revealed under certain environmental conditions. The observed embryo survival rates in our laboratory are high compared to more natural conditions [38], especially so in our first experiment, i.e. we incubated the embryos under conditions that may be less challenging than they would usually experience in the wild, giving lower quality embryos a higher survival chance. If so, it is possible that we missed some kinds of sire effects on embryo survival that may be revealed under more challenging conditions.

\section{Conclusion}

Some theory of sexual selection predicts that dominant and older males provide better genes to their offspring than subdominant and younger males. We found that larger, heavier, and older Brown trout male are indeed more dominant in male-male interactions, but females may not improve their offspring's genetic viability by mating with such males. Any advantage of mating with dom- inant males in brown trout may therefore be linked to a possibly increased fertilization success (but see [58-60]), potential benefits linked to the nest site [3], or to genetic advantages that are more context-dependent and not revealed at our experimental conditions [61] - even if we can demonstrate significant additive genetic variation for embryo viability under such conditions.

\section{Methods}

\section{First experiment}

We caught 10 males by electric fishing in the River Müsche (Kt. Bern, Switzerland) shortly before the breeding season. We then introduced them into an experimental channel $($ volume $=10 \times 0.7 \times 0.65 \mathrm{~m}$, with gravel ground and several hiding places) in order to record their dominance behaviour. We recorded the winner and the loser of all antagonistic encounters $(n=198)$ during 8 observation days over a period of 32 days. The behaviour was recorded with 10 video surveillance cameras (CCD cam 1/3" SONY Super HAD, lens angle $78^{\circ}$, minimum illumination 0.05 Lux, Profiline ${ }^{\circledR}$ ) linked to a MultiCam GV-1000 System $\left(\right.$ Ecoline $\left.^{\circledast}\right)$. Antagonistic encounters were defined as interactions between two males that resulted in one male leaving the spot of the interaction, or leaving it first. These interactions usually involved display behaviours, bites, and/or chases. To calculate dominance ranks, we used David's Score (DS) [62,63] and Clutton-Brock et al.'s index (CBI) [64], two methods that take the relative strength of the opponent into account. 
After the observation period we recorded male body length, weight and age (determined from yearly growth rings on scale samples). The 10 males and 8 females from the same river were narcotised and the eggs and milt stripped individually into separate containers. The eggs of the females were equally distributed to 10 Petri dishes each. Ten $\mu \mathrm{l}$ of milt of one of the ten males' were added in such a way that all possible sibships $(10 \times 8=80)$ were produced (full-factorial breeding; [39]). Then, every Petri dish was half filled with water and shaken gently for about 5 seconds. Within the next ten hours all eggs were distributed (one egg per well in $2 \mathrm{ml}$ of water) to 24-well Multiwell Plates (BD Falcon; nontreated polystyrene, flat bottom). The water we used for fertilisation and for incubation was standardized reconstituted water according to the OECD guideline for testing of chemicals [65]. The water volume per developing embryo corresponds to the ratio that [66] had used. Eggs of all 80 combinations ( $\mathrm{n}=$ 2028 with $23.56 \pm 10.24$ (mean \pm std deviation) eggs per combination) were incubated at one of two incubation temperatures $\left(6.9^{\circ} \mathrm{C}\right.$ and $\left.8.9^{\circ} \mathrm{C}\right)$. Water was not changed during the experiment. Egg viability was measured as the survival of visible embryos until hatching, i.e. we excluded apparently non-fertilized eggs and embryos that died before they were visible under a stereomicroscope (Olympus SZX9).

\section{Second experiment}

Brown trout were collected from their natural spawning place in River Enziwigger (Kt. Luzern, Switzerland) in November by electro-fishing. Thirteen mature males were measured for length and weight, and their age was determined from yearly growth rings on scales sampled below the adipose fin near the lateral line. Their milt was stripped for in vitro fertilization of the eggs of six females of the same population in again a full-factorial set-up (North Carolina II design). We used $20 \mu \mathrm{l}$ milt per 80-100 eggs (see [66], for the detailed methods). The resulting embryos were reared in 3 separate Petri dishes per sibship in $50 \mathrm{ml}$ sand-filtered lake water at $4.7^{\circ} \mathrm{C}$ (mean number of eggs per Petri dish: $20.4 \pm 14.1$ s.d.). From day 46 after fertilization on, inviable embryos and hatched larvae were recorded and carefully removed from the Petri dishes with a plastic spoon (in regular intervals of about 10 days each). Water was exchanged twice (at day 76 and day 88 after fertilization). Embryo viability was determined for each Petri dish as the number of hatchlings per total number of eggs.

Alevins were kept in darkness in running water at $7-8^{\circ} \mathrm{C}$ until all embryos had hatched and most alevins had nearly used up their yolk sac, i.e. until day 131 after fertilization. We then released all fish plus some additional ones (Evanno, unpublished data) into a $600 \mathrm{~m}$ long streamlet that is confined by two waterfalls. This struc- tured streamlet has a width of up to half a meter and an average depth of about $10 \mathrm{~cm}$. We removed all trouts by electrofishing and released our fish by carefully distributing them over the full length of the streamlet during a period when water discharge was low and not obviously affecting the larvae. We caught the fish back 20 months later by electrofishing. DNA was extracted from fin clips using the DNeasy Tissue kit (Qiagen) following manufacturer instructions. Eight microsatellite markers were used to determine paternity: Mst85 [67], Mst543AE, BS131, T313 [68], AETG1 [69], Ssosl417 [70], Ssa 171 [71] and Str58 [72]. PCR reactions were performed in $10 \mu \mathrm{L}$ reaction mixtures containing $2.5 \mu \mathrm{L}$ of DNA template, $1 \times$ PCR buffer (Qiagen), $1.5-2 \mathrm{mM} \mathrm{MgCl} 2,0.2 \mathrm{mM}$ dNTPs, $0.5 \mu \mathrm{M}$ of each primer and 0.25 units of Taq DNA polymerase (Applied Biosystems or Qiagen). PCR profile consisted in 30 iterations of $95^{\circ} \mathrm{C}$ for $30 \mathrm{~s}, 50^{\circ} \mathrm{C}$ (Mst85, BS131), $55^{\circ} \mathrm{C}$ (Ssa 171, Ssosl417, Str58), $58^{\circ} \mathrm{C}(M s t 543 A E)$ or $60^{\circ} \mathrm{C}$ (AETG1, T3-13) for $30 \mathrm{~s}, 72^{\circ} \mathrm{C}$ for $30 \mathrm{~s}$ and a final extension at $72^{\circ} \mathrm{C}$ for $5 \mathrm{~min}$. PCR products were analyzed with an ABI 3100 automated DNA sequencer (Applied Biosystems) using the Genemapper software (Applied Biosystems). Paternity was established using the CERVUS program [73].

\section{Statistical analyses}

In the first experiment where embryos were raised singly, we analysed embryo mortality as binary response variable with logistic mixed-effect models (every embryo as one independent data point; dead before hatching or hatched). We entered rearing temperature as fixed effect, and parent identity as random male, female, and male $\times$ female interaction effects. To test whether male, female and male $\times$ female interaction effects explain a significant part of the variance in offspring mortality, we fitted a "full model" (including all effects), a "reference model" (including temperature, male and female effects only), a "female model" (including temperature and female effects only) and a "male model" (including temperature and male effects only) and tested if the goodness of fit between models differed. The goodness of fit is given both by the logarithm of the approximated likelihood $(\ln L)$ and by the Akaikes information criterion (AIC)[74]. The latter is based on the $\ln L$ but punishes for the number of included parameters $(\mathrm{k})$ and is calculated as $A I C_{\mathrm{i}}=-2 \ln L_{\mathrm{i}}+2 \mathrm{k}_{\mathrm{i}}$. The AIC favours models that have a high goodness of fit with the smallest number of entered parameters. To test if models differ in their goodness of fit, we compared the models with likelihood ratio tests (LRT), calculated as: $\chi^{2}$ $=2\left(\ln L_{1}-\ln L_{2}\right)$. The degree of freedom is the difference in number of free parameters in the two models. The test statistic is then evaluated under the assumption of asymptotic convergence to a $\chi^{2}$ distribution. A second measure that compares the quality of fit between two models is given as the difference of AICs $(\triangle A I C)$, which is here 
calculated as $\Delta_{\mathrm{i}} A I C=A I C_{\mathrm{i}}-A I C_{\text {Reference Model }}$. An $\triangle A I C \leq 2$ indicates substantial support that the two models do not differ in the quality of fit, values between 4 and 10 indicate some support that they differ in the quality of fit, and $\triangle A I C \geq 10$ provide much support that the models differ in their quality of fit $[75,76]$. Analyses were done with the R software [77] and we used the lme4 package for logistic mixed effect model analyses [78].

Embryo mortality in the second experiment was determined for batches of embryos each. We could therefore calculate a two-way ANOVA with the sire and dam identity and sire $\times$ dam interaction as random effects and mortality per Petri dish (square-root arcsin transformed) as response variable. This analysis was done with JMP In statistical package JMP V [79]. Graphical inspection of the juvenile survival data suggested that the assumptions of parametric statistics might be significantly violated and hence non-parametric statistics (Spearman rank order correlation coefficients $r_{s}$ ) was used. All p-values are twotailed.

\section{Authors' contributions}

$\mathrm{AJ}, \mathrm{AB}$ and $\mathrm{CW}$ conceived the first experiment and did the experimental breeding. AJ determined the dominance scores. $\mathrm{AJ}$ and $\mathrm{AB}$ recorded embryo mortality and hatching date. CW and RM conceived the second experiment and did the experimental breeding, CW recorded embryo mortality. RM, CW, and AJ released the hatchlings into the streamlet and caught them back 20 months later. GE did the molecular analyses on the parents and the juveniles of the second experiment. SN, AJ and CW analysed the data. AJ and CW wrote the manuscript. All authors read and approved the final manuscript.

\section{Acknowledgements}

We thank P. Amrein, M. Flück, U. Gutmann, and H. Walther for providing the fish and for various kinds of support, M. Bia and A. Steffen for assistance, and D. Bittner, A. Champigneulle, P. Fitze, R. Gingold, C. Kropf, T. Pfeiffer, B. von Siebenthal, D. Urbach, and the anonymous referees for discussion and useful comments. The study was supported by the Swiss National Science Foundation.

\section{References}

I. Garant D, Dodson JJ, Bernatchez L: Differential reproductive success and heritability of alternative reproductive tactics in wild Atlantic salmon (Salmo salar L.). Evolution 2003, 57(5): || $|33-||4|$.

2. Andersson MB: Sexual selection. New Jersey, Princeton University Press; 1994.

3. Blanchfield PJ, Ridgway MS: The cost of peripheral males in a brook trout mating system. Anim Behav 1999, 57:537-544.

4. Wiley RH: Territoriality and non-random mating in the sage grouse Centrocercus urophasiasus. Anim Behav Monogr 1973, 6:87-169.

5. Dewsbury DA: Dominance rank, copulatory-behavior, and differential reproduction. $Q$ Rev Biol 1982, 57(2): 135-159.

6. Gibson RM: Bivariate versus multivariate analyses of sexual selection in Red deer. Anim Behav 1987, 35:292-293.
7. Mjolnerod IB, Fleming IA, Refseth UH, Hindar K: Mate and sperm competition during multiple-male spawnings of Atlantic salmon. Can J Zool I998, 76(1):70-75.

8. Dickerson BR, Brinck KW, Willson MF, Bentzen P, Quinn TP: Relative importance of salmon body size and arrival time at breeding grounds to reproductive success. Ecology 2005, 86(2):347-352.

9. Kitano S: Size-related factors causing individual variation in seasonal reproductive success of fluvial male Dolly Varden (Salvelinus malma). Ecol Freshw Fish 1996, 5(2):59-67.

10. Bekkevold D: Male size composition affects male reproductive variance in Atlantic cod Gadus morhua $L$. spawning aggregations. J Fish Biol 2006, 69(3):945-950.

II. Kokko H: Treat 'em mean, keep 'em (sometimes) keen: evolution of female preferences for dominant and coercive males. Evol Ecol 2005, 19(2): 123-135.

12. Candolin U: Male-male competition ensures honest signaling of male parental ability in the three-spined stickleback (Gasterosteus aculeatus). Behav Ecol Sociobiol 2000, 49(I):57-61.

13. Candolin U: Increased signalling effort when survival prospects decrease: male-male competition ensures honesty. Anim Behav 2000, 60:417-422.

14. Qvarnstrom A, Griffith SC, Gustafsson L: Male-male competition and parental care in collared flycatchers (Ficedula albicollis): an experiment controlling for differences in territory quality. Proc R Soc Lond B Biol Sci 2000, 267( ( 46 I ):2547-2552.

15. Bisazza A, Marconato A, Marin G: Male competition and female choice in Padogobius martensi (Pisces, Gobiidae). Anim Behav 1989, 38:406-413.

16. Neff BD, Pitcher TE: Genetic quality and sexual selection: an integrated framework for good genes and compatible genes. Mol Ecol 2005, I 4(I):19-38.

17. Qvarnstrom A, Forsgren E: Should females prefer dominant males? Trends Ecol Evol 1998, I 3(I 2):498-50।.

18. Wedekind C: Sexual selection and life-history decisions: implications for supportive breeding and the management of captive populations. Conserv Biol 2002, 16:1204-|2|1.

19. Kirkpatrick M, Ryan MJ: The Evolution of Mating Preferences and the Paradox of the Lek. Nature 1991, 350(63 I3):33-38.

20. Petrie M, Roberts G: Sexual selection and the evolution of evolvability. Heredity 2007, 98(4): 198-205.

21. Tomkins JL, Radwan J, Kotiaho JS, Tregenza T: Genic capture and resolving the lek paradox. Trends Ecol Evol 2004, 1 9(6):323-328.

22. Moller AP, Alatalo RV: Good-genes effects in sexual selection. Proc R Soc Lond B Biol Sci 1999, 266( I4 I 4):85-9I.

23. Keyser AJ, Hill GE: Structurally based plumage coloration is an honest signal of quality in male blue grosbeaks. Behav Ecol 2000, I I (2):202-209.

24. Milinski M, Bakker TCM: Female sticklebacks use male coloration in mate choice and hence avoid parasitized males. Nature 1990, 344(6264):330-333.

25. Petrie M: Improved growth and survival of offspring of peacocks with more elaborate trains. Nature 1994, 37 I (6498): 598-599.

26. Petrie $M$, Halliday $T$ : Experimental and natural changes in the peacocks (Pavo cristatus) train can affect mating success. Behav Ecol Sociobiol I994, 35(3):213-2I7.

27. Wedekind C, Müller R, Spicher H: Potential genetic benefits of mate selection in whitefish. J Evol Biol 200I, 14:980-986.

28. Welch AM, Semlitsch RD, Gerhardt HC: Call duration as an indicator of genetic quality in male gray tree frogs. Science 1998, 280(537I): 1928-1930.

29. Fleming IA: Pattern and variability in the breeding system of Atlantic salmon (Salmo salar), with comparisons to other salmonids. Can J Fish Aquat Sci 1998, 55:59-76.

30. Garant D, Dodson JJ, Bernatchez L: A genetic evaluation of mating system and determinants of individual reproductive success in Atlantic salmon (Salmo salar L.). J Hered 200I, 92(2): $137-145$

3I. Largiader CR, Estoup A, Lecerf F, Champigneulle A, Guyomard R: Microsatellite analysis of polyandry and spawning site competition in brown trout (Salmo trutta L.). Genet Sel Evol 200I, 33:S205-S222.

32. Quinn TP, Foote CJ: The effects of body-size and sexual dimorphism on the reproductive behavior of Sockeye-salmon, Oncorhynchus nerka. Anim Behav 1994, 48(4):75I-76I. 
33. Quinn TP, Hendry AP, Buck GB: Balancing natural and sexual selection in sockeye salmon: interactions between body size, reproductive opportunity and vulnerability to predation by bears. Evol Ecol Res 200I, 3(8):917-937.

34. Weir LK, Hutchings JA, Fleming IA, Einum S: Dominance relationships and behavioural correlates of individual spawning success in farmed and wild male Atlantic salmon, Salmo salar. J Anim Ecol 2004, 73(6): 1069-1079.

35. de Gaudemar B, Bonzom JM, Beall E: Effects of courtship and relative mate size on sexual motivation in Atlantic salmon. J Fish Biol 2000, 57(2):502-5I5.

36. Petersson E, Jarvi T, Olsen H, Mayer I, Hedenskog M: Male-male competition and female choice in brown trout. Anim Behav 1999, 57:777-783.

37. Blanchfield PJ, Ridgway MS: The relative influence of breeding competition and habitat quality on female reproductive success in lacustrine brook trout (Salvelinus fontinalis). Can J Fish Aquat Sci 2005, 62( ( 2):2694-2705.

38. Bradford MJ: Comparative review of Pacific salmon survival rates. Can J Fish Aquat Sci 1995, 52(6): I 327-I338.

39. Lynch $M$, Walsh $B$ : Genetics and analysis of quantitative traits. Sunderland, Massachusetts, Sinauer Associates Inc; 1998.

40. Foote CJ, Brown GS, Wood CC: Spawning success of males using alternative mating tactics in sockeye salmon, Oncorhynchus nerka. Can J Fish Aquat Sci 1997, 54(8): I 785-I795.

4I. Fleming IA, Gross MR: Breeding competition in a Pacific salmon (coho: Oncorhynchus kisutch): Measures of natural and sexual selection. Evolution 1994, 48(3):637-657.

42. Keenleyside MHA, Dupuis HMC: Courtship and spawning competition in pink salmon (Oncorhynchus gorbuscha). Can J Zool 1988, 66(I):262-265.

43. Esteve M: Observations of spawning behaviour in Salmoninae: Salmo, Oncorhynchus and Salvelinus. Rev Fish Biol Fish 2005, I 5( I2): |-2I.

44. Weatherhead PJ, Dufour KW, Lougheed SC, Eckert CG: A test of the good-genes-as-heterozygosity hypothesis using redwinged blackbirds. Behav Ecol 1999, I 0(6):619-625

45. Einum S, Fleming IA: Selection against late emergence and small offspring in Atlantic salmon (Salmo salar). Evolution 2000, 54(2):628-639.

46. Einum S, Hendry AP, Fleming IA: Egg-size evolution in aquatic environments: does oxygen availability constrain size? Proc $R$ Soc Lond B Biol Sci 2002, 269( I 507):2325-2330.

47. Einum S, Kinnison MT, Fleming IA: Evolution of egg size and number. In Evolution illuminated; Salmon and their relatives Edited by: Hendry AP, Stearns SC. New York , Oxford University Press; 2004:126-153.

48. Wedekind C, Rudolfsen G, Jacob A, Urbach D, Muller R: The genetic consequences of hatchery-induced sperm competition in a salmonid. Biol Conserv 2007, I37(2): $180-188$.

49. Snook RR: Sperm in competition: not playing by the numbers. Trends Ecol Evol 2005, 20(I):46-53.

50. Verhulst S, Salomons HM: Why fight? Socially dominant jackdaws, Corvus monedula, have low fitness. Anim Behav 2004 68:777-783.

51. Wong BBM: Superior fighters make mediocre fathers in the Pacific blue-eye fish. Anim Behav 2004, 67:583-590.

52. Brooks R, Kemp DJ: Can older males deliver the good genes? Trends Ecol Evol 200I, I6(6):308-313.

53. Kokko H, Lindstrom J: Evolution of female preference for old mates. Proc R Soc Lond B Biol Sci 1996, 263(1376): I 533-I 538.

54. Manning JT: Choosy females and correlates of male age. J Theor Biol 1985, I l 6(3):349-354.

55. Garant D, Fontaine PM, Good SP, Dodson JJ, Bernatchez L: The influence of male parental identity on growth and survival of offspring in Atlantic salmon (Salmo salar). Evol Ecol Res 2002, 4(4):537-549.

56. Hansen TF, Price DK: Good genes and old age: Do old mates provide superior genes? J Evol Biol 1995, 8(6):759-778.

57. Price DK, Hansen TF: How does offspring quality change with age in male Drosophila melanogaster? Behav Genet 1998, 28(5):395-402.

58. Berejikian B, Tezak EP: Male size effects on fertilization success: lack of evidence in chinook salmon spawning under experimental conditions. Environ Biol Fishes 2005, 72(3):235-240.
59. Dickerson BR, Willson MF, Bentzen P, Quinn TP: Size-assortative mating in salmonids: negative evidence for pink salmon in natural conditions. Anim Behav 2004, 68:38I-385

60. Figenschou L, Rudolfsen G, Folstad I: Female Arctic charr do not show apparent benefits from exposing their eggs to sperm from dominant males. J Fish Biol 2007, 71:284-289.

61. Welch AM: Genetic benefits of a female mating preference in gray tree frogs are context-dependent. Evolution 2003, 57(4):883-893.

62. David HA: The method of paired comparisons. London , Charles Griffin; 1988.

63. Gammell MP, De Vries H, Jennings DJ, Carlin CM, Hayden TJ: David's score: a more appropriate dominance ranking method than Clutton-Brock et al.'s index. Anim Behav 2003, 66:60I-605.

64. Clutton-Brock TH, Albon SD, Gibson RM, Guinness FE: Logical stag - adaptive aspects of fighting in red deer (Cervus elaphus $L$ ). Anim Behav 1979, 27(FEB):21 I-225.

65. OECD: Guideline 203: fish, accute toxicity test. Organisation for Economic Co-operation and Development. ; 1992.

66. Wedekind $C$, Müller $\mathrm{R}$ : The experimental rearing of large salmonid eggs in Petri dishes. Funct Ecol 2004, I 8(I): | 38-| 40.

67. Presa P, Guyomard R: Conservation of microsatellites in three species of salmonids. J Fish Biol 1996, 49(6): I 326-I329.

68. Estoup A, Rousset F, Michalakis Y, Cornuet JM, Adriamanga M, Guyomard R: Comparative analysis of microsatellite and allozyme markers: a case study investigating microgeographic differentiation in brown trout (Salmo trutta). Mol Ecol 1998, 7(3):339-353.

69. Estoup A, Presa P, Krieg F, Vaiman D, Guyomard R: $(\mathbf{C t})(\mathbf{N})$ and (Gt)(N) Microsatellites - a New Class of Genetic-Markers for Salmo-Trutta L (Brown Trout). Heredity 1993, 7 I:488-496.

70. Slettan A, Olsaker I, Lie O: Atlantic Salmon, Salmo-Salar, Microsatellites at the SsosI25, Ssosl85, Ssosl3 I I, Ssosl4I 7 Loci. Anim Genet 1995, 26(4):28I-282.

7I. Oreilly PT, Hamilton LC, McConnell SK, Wright JM: Rapid analysis of genetic variation in Atlantic salmon (Salmo salar) by PCR multiplexing of dinucleotide and tetranucleotide microsatellites. Can J Fish Aquat Sci 1996, 53( I 0):2292-2298.

72. Poteaux C, Bonhomme F, Berrebi P: Microsatellite polymorphism and genetic impact of restocking in Mediterranean brown trout (Salmo trutta L.). Heredity 1999, 82:645-653.

73. Marshall TC, Slate J, Kruuk LEB, Pemberton JM: Statistical confidence for likelihood-based paternity inference in natural populations. Mol Ecol 1998, 7(5):639-655.

74. Akaike $\mathrm{H}$ : New look at the statistical model identification. IEEE Trans Aut Contr 1974, AC-19(6):716-723.

75. Sullivan J, Joyce P: Model selection in phylogenetics. Annu Rev Ecol Evol Syst 2005, 36:445-466.

76. Burnham KP, Anderson DR: Multimodel inference - understanding AIC and BIC in model selection. Sociol Method Res 2004, 33(2):26I-304.

77. R Development Core Team: R: A language and environment for statistical computing. 2006 [http://www.R-project.org]. Vienna, Austria , R Foundation for Statistical Computing

78. Bates D, Sarkar D: Ime4: Linear mixed-effects models using S4 classes. 2007:R package version 0.9975-I3.

79. JMP V: JMP. [http://www.jmp.com]

Publish with Bio Med Central and every scientist can read your work free of charge

"BioMed Central will be the most significant development for disseminating the results of biomedical research in our lifetime. "

Sir Paul Nurse, Cancer Research UK

Your research papers will be:

- available free of charge to the entire biomedical community

- peer reviewed and published immediately upon acceptance

- cited in PubMed and archived on PubMed Central

- yours - you keep the copyright
BioMedcentral 